\title{
EFFECT OF USING BIOAKTIV OXYGEN ACTIVATED SODIUM CHLORIDE AS A NOVAEL ALTERNATIVE TO ANTIBIOTIC IN DRINKING WATER ON PERFORMANCE AND ENZYMES ACTIVITY OF BROILER CHICKS.
}

\author{
M.H.S. El-Sanhoury \\ Poultry Production Department, Faculty of Agriculture, Ain Shams University, Cairo, Egypt
}

(Received 3/7/2017, accepted 11/8/2017)

\section{SUMMARY}

$\mathrm{T}$ The study was designed to examine effects of using graded levels of oxygen activated sodium chloride (BioAktiv) in comparison to antibiotic on performance, serum metabolites and digestive enzymes activity in broiler chicks. One hundred eighty, one day old Ross broiler chicks were randomly allocated to four groups. The first group was control without water supplementation. While, the $2^{\text {nd }}$ and $3^{\text {rd }}$ groups received 0.5 and $1 \mathrm{gm} / 1 \mathrm{~L}$ drinking water BioAktiv, respectively. The $4^{\text {th }}$ one was given 500 ppm streptomycin (commercial streptomycin 5\%) antibiotic. Chicks received the 4 experimental treatments up to the age of 35 day of age. Chicks given different levels of BioAktiv, recorded higher live body weight (LBW) and body weight gain (BWG), better feed conversion ratio (FCR) comparable to both antibiotic and control groups. The highest ( $\mathrm{p}<0.01$ ) digestive enzyme activities (amylase, protease) were reported for chicks given $\mathrm{NaCl} \mathrm{gm} / 1 \mathrm{~L}$ BioAktiv, followed by those of antibiotic and the control groups. Highly significant increase $(\mathrm{p}<0.01)$ in the serum concentration of total proteins and globulin was observed in groups received the different levels of BioAktiv compared to those of the untreated and antibiotic ones, Likewise, the levels of serum $T_{3}$ and $T_{3} / T_{4}$ ratio;recorded higher level with treated groups, however, $T_{4}$ value was insignificantly differed among all groups. Beyond, watery BioAktiv addition had hypolipemic and hypocholesterolemic effects, but had no effect on liver and kidney functions. These findings imply that, BioAktivmight be considered as a safe water-added antibiotic alternative having affirmative effect on growth performance, gastrointestinal tract (GIT) health and the physiological homeostasis of broiler chicks.

Keywords: broiler, water, BioAktiv, serum, $T_{3}$, GIT enzymes.

\section{INTRODUCTION}

The ban of using antibiotics in poultry feeds has led to increase research for safer alternatives belonging to the group of Eubiotics (organic acids, plant extracts, prebiotics, probiotics, enzymes and many other products modulating the gut microflora).

They have recently been pointed out to the novel safe product BioAktiv Animal Food Additive, manufactured in a bio resonant process, in which resonances are produced within the natural vibration of pure Sodium Chloride from north-German Sodium Chloride deposits and oxygen. This takes place in a physical manner, without chemical processing or mixing with other substances (BioActiv, 1999). Moreover, it has a combination of Homeopathic Frequency Information accumulated or loaded into it. Thereby, it operates as a "biological conditioner" and is designed to influence and improve the natural bacterial processes that occur in the digestive system and the overall health of the animal (Gaughan et al., 2007 and Borsenberger, 2008). BioAktiv comes in either a powdered formula, which is simply added to poultry feed, or a liquid solution added to the bird's drinking water.

Research conducted overseas which has indicated that BioAktiv improves feed digestibility, improves the immune system and reduces methane, ammonia and nitrous oxide production.

To our knowledge, there are scarce available literatures concerning the effect of using BioAktiv in broiler production. Moreover, the accessible information is mostly derived from results of either experiment or project reports. Therefore, the aim of this study was to assess the effect of using BioAktiv as a novel alternative to antibiotic on the growth performance and some physiological in broiler chicks. 


\section{El-Sanhoury}

\section{MATERIALS AND METHODS}

A total number of 180 one d-old Ross broiler chicks were used in this study. The broiler chicks were nearly equal in the live body weight and divided randomly into four treatment groups of 45 chicks each. Each experimental group was divided into five replicates ( 9 chicks/each). The first group was control and drinks the basal water. While, the $2^{\text {nd }}$ and $3^{\text {rd }}$ groups were drink water supplemented with 0.5 and $1 \mathrm{gm} /$ $1 \mathrm{~L}$ BioAktiv, respectively. The $4^{\text {th }}$ one was given the basal water contained antibiotic. BioAktiv is a sodium chloride which has a similar chemical composition as salt, but has undergone a special treatment (oxygen activation). Antibiotic was streptomycin (commercial streptomycin 5\%) as growth promoter. This study was terminated when the birds were 35 days old.

Table (1): Composition of diets and Chemical analysis

\begin{tabular}{|c|c|c|c|c|}
\hline Ingredients (\%) & $\begin{array}{c}\text { Before Pre-Starter } \\
\text { (1-5days) }\end{array}$ & $\begin{array}{l}\text { Pre-Starter } \\
\text { (6-11days) }\end{array}$ & $\begin{array}{c}\text { Starter } \\
(12-21 \text { days })\end{array}$ & $\begin{array}{c}\text { Grower } \\
\text { (22-35days) }\end{array}$ \\
\hline Yellow corn & 46.5 & 53.85 & 56 & 63 \\
\hline Soybean meal (44\%CP) & 31 & 28 & 23.3 & 17.9 \\
\hline soy full fat $37 \%$ & 18 & 14 & 17 & 16 \\
\hline di cal phos & 2 & 1.8 & 1.75 & 1.45 \\
\hline Limestone & 1 & 1 & 0.85 & 0.8 \\
\hline Vit \& Min Premix* & 0.3 & 0.3 & 0.3 & 0.3 \\
\hline $\mathrm{NaCl}$ & 0.25 & 0.25 & 0.25 & 0.25 \\
\hline Lysine & 0.35 & 0.3 & 0.15 & 0.05 \\
\hline DL-Methionine & 0.35 & 0.3 & 0.25 & 0.13 \\
\hline Threonine & 0.125 & 0.1 & 0.05 & 0.025 \\
\hline Anti-toxin & 0.1 & 0.1 & 0.1 & 0.1 \\
\hline Total & 100 & 100 & 100 & 100 \\
\hline \multicolumn{5}{|l|}{ Chemical analysis:- } \\
\hline \multicolumn{5}{|l|}{ A-Determined analysis: } \\
\hline Crude protein $\%$ & 23.64 & 21.43 & 20.34 & 18.08 \\
\hline Crude fiber $\%$ & 4.57 & 4.28 & 4.32 & 4.03 \\
\hline Ether extract \% & 5.84 & 5.27 & 5.88 & 5.86 \\
\hline Ash \% & 7.01 & 6.52 & 6.27 & 5.63 \\
\hline \multicolumn{5}{|l|}{ B-Calculated analysis: } \\
\hline $\mathrm{ME}(\mathrm{Kcal} / \mathrm{Kg}$ diet $)$ & 2996 & 3006 & 3066 & 3136 \\
\hline Calcium $\%$ & 1.11 & 1.05 & 0.97 & 0.86 \\
\hline Available phosphorous $\%$ & 0.56 & 0.50 & 0.49 & 0.43 \\
\hline Lysine \% & 1.75 & 1.54 & 1.35 & 1.10 \\
\hline Methionine \% & 0.93 & 0.82 & 0.76 & 0.59 \\
\hline Meth. + Cys. \% & 1.12 & 1.01 & 0.93 & 0.76 \\
\hline
\end{tabular}

The experimental period included four feeding phases (Before Pre-Starter, from 1-5 days of age, PreStarter, from 6-11days of age, starter, from 12-21 days of age and grower, from 22-35days of age). The experimental diets were formulated to nearly meet the nutrient requirements of the broilers (NRC, 1994). The composition and chemical analysis of the diets are presented in Table 1. The chemical composition of the experimental diets was analyzed according to AOAC. (2005).

Feed and water were supplied ad-libitium during the experimental period. Chicks were grown in floors divided groups and exposed to 24 hours of constant light. All chicks were kept under the same managerial, hygienic and environmental conditions. Chicks were individually weight at the beginning of the experiment, then at weekly intervals until the end of experiment. Live body weight (LBW), body weight gain (BWG), feed consumption (FC), feed conversion ratio (FCR, g feed/g gain) were recorded during these periods. 
At the age of $35 \mathrm{~d}$, ten birds ( 5 males and 5 females) from each experimental group were weighed and slaughtered by slitting the jugular vein, then scalded and de-feathered. Carcasses were manually eviscerated and weighted. Liver, heart, gizzard, spleen, thymus (all lobes of both sides), bursa, ileum and abdominal fat were removed and their relative percentages of live body weight were estimated. The proventriculus and ileum were emptied by gentle squeezing, contents of individual segments were taken and mixed then about $1 \mathrm{~g}$ of the mixed content was immediately diluted with $10 \mathrm{ml}$ of distilled water. All samples were centrifuged for 10 minutes. The supernatant fluid was taken and stored in sealed bottles at $20^{\circ} \mathrm{C}$ until analyzed. Enzymes activity in digestive content of proventriculus and ileum of chicks were determined as follows: amylase (Osman, 1982) and protease (Malik and Singh, 1980).

Blood samples were collected from the ten slaughtered birds in nonheparinized tubes. The blood samples were centrifuged at $3000 \mathrm{rpm}$ for $15 \mathrm{~min}$. and serum obtained was stored at -20C until analysis. Serum total protein, albumin, total lipid, cholesterol, creatinine, aspartate aminotransferase (AST) and alanine aminotransferase (ALT) were determined calorimetrically by using available commercial kits purchased from Diamond Diagnostics Company. The globulin values were calculated by subtracting the values of albumin from the corresponding values of total protein. Serum concentration of triiodothyronine $\left(\mathrm{T}_{3}\right)$ and thyroxine $\left(\mathrm{T}_{4}\right)$ were determined by RIA technique using commercial RIA kits (Immunotech, Beckman Coult. Company).

\section{Statistical analysis:}

Data were statistically analyzed by using the General Linear models (GLM) procedures of SAS (SAS, 2004). The model was as follows: $\mathrm{Yij}=\mu+\mathrm{Ti}+\mathrm{eij}$.

Where: $\mathrm{Yij}=$ The observation on the $\mathrm{I}^{\text {th }}$ treatment $\mu=$ Overall mean, Ti $=$ Effect of the $\mathrm{I}^{\text {th }}$ treatment, eij = Random error treatment. Significant differences among treatment means were determined by Duncan's multiple range test (Duncan, 1955). All Percentage data were subjected to arcsine transformation of the square root before statistically reanalyzed however, the actual percentage means are presented.

\section{RESULTS AND DISCUSSION}

Good intestinal health will lead to a better growth rate and feed efficiency in poultry. The effect of using graded levels of oxygen activated Na CL (BioAktiv) on body weight (LBW) and body weight gains (BWG) are presented in Table (2). The results showed highly significant increase in the LBW and BWG of broiler chicks drink different levels of BioAktiv followed by those drink water supplemented with antibiotic, while the un-supplemented control group had the lower values. Besides, the improvement in both LBW and BWG, it was more evident at 21 and 35 DOA for chicks whose drink water contained Na CL0.5gm/1L and $\mathrm{Na}$ CL1gm/1L BioAktiv, respectively. Similar trend was watched for the feed conversion ratio (FCR) whether through the first three week of age or the cumulative FCR from 1-35 DOA. In which, the control group recorded the worst value followed by those drink water supplemented with antibiotic. The present findings are coincided with those mentioned by Borsenberger (2008) who illustrated that dietary administration of BioAktiv stimulated the aerobic (beneficial) bacteria and reduced the level of anaerobic (harmful) bacteria in the birds gut, thus improved the digestion and increasing the immune system. Consequently, improved FCR due to enhancing digestion, and extend a healthier intestinal environment for better absorption of the nutrients (Bonneau and Laarveld, 1999). As well BioAktiv has the ability of making birds calmer enabling them to feed and gain easily. Moreover, the BioAktiv decreases the ammonia in the poultry buildings resulting in healthier poultry. With the application of BioAktiv in pig production, Gaughan et al. (2007) reported that it operates as a "biological conditioner" and is designed to influence and improve the natural bacterial process that occur in the digestive system and the overall health of the animal. They also added that BioAktiv improved digestibility of feed and the immune system, reduced methane, ammonia and nitrous oxide production, and that animals fed on feeds containing BioAktiv are calmer and quieter than those fed un-supplemented diets. The achieved superior effect of using the oxygen activated $\mathrm{Na}$ CL (BioAktiv) on the productive performance of broilers rather than the antibiotic is referred to the bacterial development resistance and potential consequences on the human health with supplemental antibiotic (Phillip et al., 2004 and Samik et al., 2007). The reason why replacement materials which control the pathogen microorganisms such as Salmonella and Coliforms and boost the digestive microflora with beneficial microorganisms were used (Shane, 2001). 


\section{El-Sanhoury}

Table (2): Effect of different levels of oxygen activated Na CL (BioAktiv) compared with antibiotic on productive performance of broiler chicks.

\begin{tabular}{|c|c|c|c|c|c|}
\hline \multirow[t]{2}{*}{ Variable } & \multicolumn{4}{|c|}{ Treatment } & \multirow[t]{2}{*}{ Prob. } \\
\hline & Control & $\mathrm{Na}$ CL0.5gm/1L & $\mathrm{Na} \mathrm{CL1gm/1L}$ & Antibiotic & \\
\hline \multicolumn{6}{|c|}{ Live body weight $(\mathrm{g})$ at } \\
\hline $1 \mathrm{~d}$ old & $44.85 \pm 0.41$ & $44.23 \pm 0.69$ & $43.70 \pm 0.89$ & $44.97 \pm 0.52$ & 0.487 \\
\hline 21d old & $685.28^{\mathrm{c}} \pm 15.42$ & $809.38^{\mathrm{ab}} \pm 19.41$ & $842.10^{\mathrm{a}} \pm 18.09$ & $764.77^{\mathrm{b}} \pm 25.78$ & 0.002 \\
\hline $35 \mathrm{~d}$ old & $1568.37^{\mathrm{c}} \pm 69.69$ & $1728.69^{\mathrm{b}} \pm 22.45$ & $1823.33^{\mathrm{a}} \pm 50.07$ & $1684.00^{\mathrm{b}} \pm 24.45$ & 0.004 \\
\hline \multicolumn{6}{|c|}{ Body weight gain $(g)$ from } \\
\hline $1-21 d$ & $640.43^{c} \pm 16.73$ & $765.15^{\mathrm{ab}} \pm 20.99$ & $798.40^{\mathrm{a}} \pm 13.41$ & $719.80^{\mathrm{b}} \pm 24.89$ & 0.002 \\
\hline $1-35 d$ & $1523.52^{c} \pm 59.87$ & $1684.46^{\mathrm{b}} \pm 31.04$ & $1779.63^{\mathrm{a}} \pm 48.59$ & $1639.03^{\mathrm{b}} \pm 41.83$ & 0.004 \\
\hline \multicolumn{6}{|c|}{ Feed conversion ratio (Feed/Gain) from } \\
\hline $1-21 d$ & $1.43^{\mathrm{a}} \pm 0.06$ & $1.39^{\mathrm{ab}} \pm 0.04$ & $1.23^{\mathrm{c}} \pm 0.05$ & $1.38^{\mathrm{ab}} \pm 0.03$ & 0.002 \\
\hline $1-35 d$ & $1.77^{\mathrm{a}} \pm 0.09$ & $1.54^{\mathrm{c}} \pm 0.03$ & $1.48^{\mathrm{d}} \pm 0.02$ & $1.62^{\mathrm{b}} \pm 0.04$ & 0.004 \\
\hline
\end{tabular}

It is interesting that, the oxidative action of oxygen activated $\mathrm{Na} C \mathrm{~L}$ (BioAktiv) in eliminating the harmful microorganism, might bear a resemblance manner to that of ozone. Amwele (2004) revealed that regular administration of ozone for broiler chicks could eliminates the bacteria by penetrating through the cell membrane and interacting with the metabolism process. This slows down and destructs the network of enzymatic systems that control the vital processes in the bacteria and damages the cell membrane, thus improving the growth rate in broilers (DEL-Agriculture, 2000 and Theruvathu et al., 2001). The high oxidation potential of ozone is component by the highly unstable tri-atomic oxygen molecule that is component by plus of an oxygen atom to molecular diatomic oxygen. In the process a considerably unstable ozone molecule is generated which rapidly degrades back to molecular oxygen releasing a free oxygen atom that combines with another free oxygen atom to form molecular oxygen or forming with other chemical moieties causing oxidation (Guzel-Seydim et al., 2004).

Table (3): Effect of different levels of oxygen activated Na CL (BioAktiv) and antibiotic on digestive enzymes activity (Unit/dl) of broiler chicks.

\begin{tabular}{|c|c|c|c|c|c|}
\hline \multirow[t]{2}{*}{ GIT segment } & \multicolumn{4}{|c|}{ Treatment } & \multirow[t]{2}{*}{ Prob. } \\
\hline & Control & $\mathrm{Na}$ CL0.5gm/1I & $\mathrm{NaCL1g}$ & Antib & \\
\hline \multicolumn{6}{|l|}{ Amylase } \\
\hline Proventriculus & $0.401^{\mathrm{d}} \pm 0.01$ & $0.719^{b} \pm 0.04$ & $0.977^{\mathrm{a}} \pm 0.03$ & $0.577^{\mathrm{c}} \pm 0.02$ & 0.0009 \\
\hline Small intestine & $39.372^{\mathrm{d}} \pm 0.71$ & $46.651^{\mathrm{b}} \pm 0.92$ & $49.639^{\mathrm{a}} \pm 0.72$ & $42.256^{\mathrm{c}} \pm 0.79$ & 0.0003 \\
\hline \multicolumn{6}{|l|}{$\underline{\text { Protease }}$} \\
\hline Proventriculus & $11.326^{\mathrm{d}} \pm 0.20$ & $13.373^{\mathrm{b}} \pm 0.31$ & $14.368^{\mathrm{a}} \pm 0.24$ & $11.875^{\mathrm{c}} \pm 0.11$ & 0.0005 \\
\hline Small intestine & $8.882^{c} \pm 0.02$ & $10.552^{\mathrm{b}} \pm 0.41$ & $12.248^{\mathrm{a}} \pm 0.27$ & $9.258^{\mathrm{b}} \pm 0.33$ & 0.0003 \\
\hline
\end{tabular}

$\overline{a, b, c, d}$ Means within the same row with different letters are significantly differ.

The pancreas is an exocrine gland and important digestive organ of birds. The pancreatic juice consists of magnificent series of digestive enzymes that are vital for digestion and absorption of feed nutrients. To our knowledge there is no available information about the underlying mechanisms by which watery supplementation of BioAktiv modulates pancreatic digestive enzymes, particularly in digestive organs such as the proventriculus and ilum. 
The pancreatic and intestinal digestion enzyme activity (amylase and protease) within the proventriculus and ileum of broiler chickens drink different experimental treatments are shown in Table (3). The main features resulted by supplementation of different dosages of BioAktiv are the noticed linear increase in the activities of these enzymes in a statistical significant manner when comparable with the both the antibiotic and control groups. Additionally, insignificant difference was found high level of BioAktiv (Na CL1gm/1L) in the action of amylase in proventriculus and small intestine, like that protease activity in small intestine. This finding may imply that increasing the water drink of BioAktiv beyond $\mathrm{Na}$ $\mathrm{CL} 1 \mathrm{gm} / 1 \mathrm{~L}$ is ineffectual in enhancement of the digestive enzyme activities under the conditions of our experiment. It is noteworthy that, the dry matter digestibility of broiler diets can vary from 50 to $80 \%$ depending upon the type of a diet, its composition and bird age (Muhammaed and Chaudhry, 2010). Denbow (2000) stated in birds that different enzymes play an imperative role in the utilization of different nutrients i.e. amylase can digest starch, lipase can digest fat and protease can digest protein. Interestingly, the accomplished increase in the digestive enzymes activity has deduced an expectable improvement in the digestibility of dry matter and nitrogen retention which has been reflected in accelerating the growth traits of broilers as verified in the current productive performance data (Table 2).

Thyroid hormones $\left(\mathrm{T}_{3}\right.$ and $\mathrm{T}_{4}$ ) concentration of broiler chicks at 5 weeks of old as affected by supplemental BioAktiv levels comparable to antibiotic and control treatments is showed in Table 4. The results showed that the drink water provision of graded levels of BioAktiv had significantly elevated the $\mathrm{T}_{3}$ level (hyperthyroidism) and the $\mathrm{T}_{3} / \mathrm{T}_{4}$ ratio, in comparison to the antibiotic and control groups, further the effect was BioAktiv dose dependent. Hence, the effect was more prominent with the high BioAktiv dosage $(\mathrm{Na} \mathrm{CL} 1 \mathrm{gm} / 1 \mathrm{~L})$ followed by the low level $(\mathrm{Na} \mathrm{CL} 1 \mathrm{gm} / 1 \mathrm{~L})$, while the lowest values were recorded for the control group. On the other hand, the serum concentration of Thyroxine $\left(\mathrm{T}_{4}\right)$ was insignificantly different among whole experimental treatments.

Table (4): Serum triiodothyronine $\left(T_{3}\right)$ and thyroxine $\left(T_{4}\right)$ of broilers fed on either antibiotic or different levels of oxygen activated Na CL (BioAktiv).

\begin{tabular}{lccccc}
\hline Variable & \multicolumn{3}{c}{ Treatment } & \multirow{2}{*}{ Prob. } \\
\cline { 2 - 4 } & Control & Na CL 0.5gm/1L & Na CL 1gm/1L & Antibiotic & \\
\hline $\mathrm{T}_{3}(\mathrm{ng} / \mathrm{ml})$ & $4.29^{\mathrm{d}} \pm 0.02$ & $4.89^{\mathrm{b}} \pm 0.03$ & $5.56^{\mathrm{a}} \pm 0.04$ & $4.48^{\mathrm{c}} \pm 0.02$ & 0.0003 \\
$\mathrm{~T}_{4}(\mathrm{ng} / \mathrm{ml})$ & $21.09 \pm 0.63$ & $20.17 \pm 0.52$ & $20.76 \pm 0.50$ & $20.46 \pm 0.71$ & 0.4020 \\
$\mathrm{~T}_{3}: \mathrm{T}_{4}$ & $0.203^{\mathrm{d}} \pm 0.003$ & $0.242^{\mathrm{b}} \pm 0.002$ & $0.268^{\mathrm{a}} \pm 0.001$ & $0.219^{\mathrm{c}} \pm 0.002$ & 0.0002 \\
\hline
\end{tabular}

$\overline{a, b, c}$ Means within the same row with different letters are significantly differ.

From these findings it could be assumed that the significant hyperthyroidism, height in serum $\mathrm{T}_{3}$ concentration, noted herein could be percentage to higher conversion of $T_{4}$ into $T_{3}$ to regulate the metabolic rate concomitant with the higher growth rate, especially in the BioAktiv treatments. This hyperthyroidism and peripheral conversion of $\mathrm{T}_{4}$ to $\mathrm{T}_{3}$ signified better immunocompetence and bursa growth, like that lower fat deposition (Abdel-Fattah et al., 2008).

It is worth note that, the achievement of superior growth rate due to BioAktiv administration is in association with the observed increase in the serum concentration of $\mathrm{T}_{3}$ level and $\mathrm{T}_{3} / \mathrm{T}_{4}$ ratio (Table 4). Triiodothyronine $\left(\mathrm{T}_{3}\right)$, the metabolically active thyroid hormone, added an active role in energy metabolism and metabolic rate. Any pronounced alteration in thyroid function (hyperthyroidism or hypothyroidism) is reflected in a changed metabolic rate (Wentworth and Ringer, 1986).

Concerning the effect of different experimental treatments on serum constituents, the obtained data showed linear significant increase in the total protein, albumin and globulin concentration with the inclusion of BioAktiv in broiler drink water comparable to those chicks drink water non-supplemented (Table 5).

Data of the albumin/globulin $(\mathrm{A} / \mathrm{G})$ ratio showed that control group had numerically the highest value comparable with the other treatments. Griminger (1986) stated that A/G ratio has been well known as an indicator for the metabolic activities and immune resistance. Indeed, the low A/G ratio indicates more disease resistance and immune response. The present finding concerning the effect of dietary antibiotic inclusion, are coincided with Dibner and Buttin (2002). Anjum and Chaudhry (2010) stated that antibiotic improves protein and energy digestibility by reducing the microbial competition with the host for 
nutrients, endogenous nitrogen losses and ammonia production. In a similar manner the valuable effect of BioAktiv could be percentage to the flattering environment in the (GIT) due to feeding of BioAktiv, which might have helped to digest and absorb more nitrogen. This beneficially effect is coincided with those reported by using supplemental probiotic in broiler (Arun et al., 2006) and organic acid in laying hens (Yesilbag and Colpan, 2006).

Table (5): Effect of different levels of oxygen activated Na CL (BioAktiv) compared with antibiotic on some serum constituents of broiler chicks.

\begin{tabular}{llllll}
\hline Variable & \multicolumn{4}{c}{ Treatment } & Prob. \\
\cline { 2 - 6 } & Control & Na CL0.5gm/1L & Na CL1gm/1L & Antibiotic \\
\hline Total protein $(\mathrm{g} / \mathrm{dl})$ & $4.22^{\mathrm{d}} \pm 0.14$ & $5.05^{\mathrm{b}} \pm 0.08$ & $5.35^{\mathrm{a}} \pm 0.04$ & $4.61^{\mathrm{c}} \pm 0.09$ & 0.0002 \\
Albumin $(\mathrm{A})(\mathrm{g} / \mathrm{dl})$ & $1.91^{\mathrm{c}} \pm 0.06$ & $2.10^{\mathrm{b}} \pm 0.03$ & $2.16^{\mathrm{a}} \pm 0.02$ & $1.93^{\mathrm{c}} \pm 0.03$ & 0.0004 \\
Globulin $(\mathrm{G})(\mathrm{g} / \mathrm{dl})$ & $2.31^{\mathrm{d}} \pm 0.13$ & $2.95^{\mathrm{b}} \pm 0.11$ & $3.19^{\mathrm{a}} \pm 0.09$ & $2.68^{\mathrm{c}} \pm 0.07$ & 0.0003 \\
A/G ratio & $0.83 \pm 0.10$ & $0.71 \pm 0.06$ & $0.68 \pm 0.05$ & $0.72 \pm 0.07$ & 0.241 \\
cholesterol $(\mathrm{mg} / \mathrm{dl})$ & $128.4^{\mathrm{b}} \pm 1.86$ & $121.3^{\mathrm{c}} \pm 1.24$ & $116.13^{\mathrm{d}} \pm 1.43$ & $134.99^{\mathrm{a}} \pm 1.09$ & 0.007 \\
Total lipid $(\mathrm{mg} / \mathrm{dl})$ & $465.97^{\mathrm{a}} \pm 13.09$ & $402.74^{\mathrm{b}} \pm 13.29$ & $376.64^{\mathrm{c}} \pm 7.12$ & $452.23^{\mathrm{a}} \pm 15.34$ & 0.023 \\
Creatinine $(\mathrm{mg} / \mathrm{dl})$ & $0.91^{\mathrm{a}} \pm 0.01$ & $0.84^{\mathrm{b}} \pm 0.02$ & $0.82^{\mathrm{b}} \pm 0.02$ & $0.89^{\mathrm{a}} \pm 0.01$ & 0.002 \\
AST (U/L) & $30.72^{\mathrm{a}} \pm 1.14$ & $27.94^{\mathrm{b}} \pm 0.87$ & $24.92^{\mathrm{c}} \pm 0.89$ & $26.97^{\mathrm{b}} \pm 1.30$ & 0.019 \\
ALT $(\mathrm{U} / \mathrm{L})$ & $45.62 \pm 1.53$ & $43.43 \pm 1.36$ & $42.83 \pm 1.39$ & $44.12 \pm 1.63$ & 0.238 \\
\hline
\end{tabular}

${ }^{a, b c}$ Means within the same row with different letters are significantly differ.

The results of cholesterol and total serum lipid showed converse trend to that reported for the total protein and its fractions. In which, their concentrations were significantly reduced due to supplemental BioAktiv; additionally the reduction was markedly evident with the higher BioAktiv level (Na $\mathrm{CL} 1 \mathrm{gm} / 1 \mathrm{~L}$ ). It is likely that BioAktiv might improve amino acid uptake by muscle cells via increasing total protein deposition like that decreasing the total lipid and total cholesterol in blood which modulate the percentage of muscles to fat content in the body. This hypothesis could be supported by the present findings of fat contents versus lean tissues observed in Table 6. As well, the observed hyperthyroidism $\left(\mathrm{T}_{3}\right.$ elevation) which induces energy metabolism and decreases fat deposition (Table 4), therefore, BioAktiv, unlike antibiotic, might increase deconjugation of bile acids caused by some gram positive bacteria resulting in greater excretion of bile acids from the intestinal tract. The increased excretion of bile acids stimulates the replacement of bile acids from cholesterol, thus reducing plasma cholesterol level (De Rodas et al., 1996). On the other hand, the hypercholesterolemia observed for the antibiotic group could be interpreted through its restraining effect on gram-positive bacteria (Yakhkeshi et al., 2011).

The end products of nitrogen metabolism excreted in the urine of birds include urates, ammonia, urea, creatinine, amino acids, and others (Goldstein and Skadhauge, 2000). From Table (5) it is obvious that, serum concentration of creatinine was reduced with the enforcement of both BioAktiv and antibiotic in broiler diet, further the effect was more pronounced with BioAktiv, indicting better utilization of dietary protein metabolism comparable with the non-supplemented in water drink control group.

As showed in Table (5). Although, there was a significant lowering in the serum level of AST in response to BioAktiv supplementation in water at the dosage of $\mathrm{Na}$ CL0.5gm/1L or Na CL1gm/1L, insignificant differences were found among all experimental groups including the control one for the ALT activity. This result might imply the lake of liver dysfunction in broiler chicks drink water contained BioAktiv.

Data showed in Table (6) observed that watery provision of oxygen activated sodium chloride (BioAktiv) increased significantly the relative carcass and liver weights and this effect was dose dependent, in spite of the absence of significance between the antibiotic treatment and Na CL0.5gm/1L BioAktiv for dressing percentage weight. As well, the relative weights of gizzard and heart were insignificantly increased due to BioAktiv supplementation comparable to both antibiotic and control groups. Concerning the abdominal fat, the current results indicated that BioAktiv treatments could 
significantly reduce the relative weights of abdominal fat comparable with the un-supplemented in water drink control one. But, they didn't significantly differ from the antibiotic control group.

Table (6): Effect of different levels of oxygen activated Na CL (BioAktiv) compared with antibiotic on relative weights of dressing and some organs in broiler chicks.

\begin{tabular}{lccccc}
\hline Variable & \multicolumn{3}{c}{ Treatment } & Prob. \\
\cline { 2 - 5 } & Control & Na CL0.5gm/1L & Na CL1gm/1L & Antibiotic \\
\hline Dressing & $64.38^{\mathrm{c}} \pm 0.94$ & $68.52^{\mathrm{b}} \pm 0.28$ & $70.78^{\mathrm{a}} \pm 0.49$ & $68.14^{\mathrm{b}} \pm 0.27$ & 0.0002 \\
Gizzard & $2.25 \pm 0.09$ & $2.45 \pm 0.03$ & $2.70 \pm 0.04$ & $2.33 \pm 0.05$ & 0.235 \\
Liver & $2.96^{\mathrm{c}} \pm 0.04$ & $3.38^{\mathrm{b}} \pm 0.02$ & $3.78^{\mathrm{a}} \pm 0.05$ & $3.31^{\mathrm{b}} \pm 0.08$ & 0.131 \\
Heart & $0.41 \pm 0.09$ & $0.47 \pm 0.07$ & $0.57 \pm 0.05$ & $0.48 \pm 0.06$ & 0.299 \\
Abdominal fat & $1.75^{\mathrm{a}} \pm 0.04$ & $1.07^{\mathrm{b}} \pm 0.05$ & $1.08^{\mathrm{b}} \pm 0.06$ & $1.09^{\mathrm{b}} \pm 0.08$ & 0.004 \\
Breast & $11.77 \pm 0.09$ & $12.79 \pm 0.08$ & $12.74 \pm 0.06$ & $12.8 \pm 0.03$ & 0.389 \\
Thigh & $4.84^{\mathrm{c}} \pm 0.09$ & $5.17^{\mathrm{b}} \pm 0.08$ & $6.25^{\mathrm{a}} \pm 0.05$ & $5.22^{\mathrm{b}} \pm 0.07$ & 0.0003 \\
Drumstick & $5.26 \pm 0.09$ & $5.36 \pm 0.03$ & $5.72 \pm 0.05$ & $5.50 \pm 0.08$ & 0.798 \\
Small Intestine & $6.68^{\mathrm{a}} \pm 0.17$ & $5.66^{\mathrm{b}} \pm 0.15$ & $5.45^{\mathrm{b}} \pm 0.06$ & $6.38^{\mathrm{a}} \pm 0.14$ & 0.0004
\end{tabular}

$\overline{\mathrm{a}, \mathrm{b} c \mathrm{c}}$ Means within the same row with different letters are significantly differ.

On opposite to the results of abdominal fat the relative thigh muscle weight had increased $(\mathrm{p}=0.004)$ with the addition of BioAktiv, and the increase was markedly observed for chicks received Na CL1gm/1L BioAktiv. Similarly, however insignificant, the breast and drumstick muscle weights were increased in chicks of BioAktiv compared to those of the antibiotic and control ones.

From these results, it is clear that water supplementation of BioAktiv exhibited statistically validated better results in terms of dressing, liver and lean percentages. These results could be account for the accelerating growth effect accomplished previously with using BioAktiv. Our results are in harmony with those reported in pig by Gaughan (2001) and in BioAktiv (1999).

With regard to the ileum weight, the collected results showed that water non supplemented control group had significantly heavier relative intestine weight than other treatments of different BioAktiv levels and antibiotic. These results may indicate better intestinal food utilization and absorption for the supplemented groups. In this respect, according to Huyghebaert et al. (2010) who recently suggested a definition for the zootechnical additives, as they are any additive other than feed material and premixtures used to affect favorably either the performance of animals in good health, the environment or both of them. More recently, Aureli et al. (2012) cited that, any product which has the potentiality to replace the antibiotic and could modulate the gut microflora are belonging to the group of Eubiotics i.e., organic acids, plant extracts, enzymes, prebiotics, probiotics and many other products. Based on these definitions, the BioAktiv may consider a class of these zootechnical or Eubiotics additives, hence it behaves similar to these additives, reducing the pathogenic bacteria in intestine and causing lighter relative intestine weight, due to thinner intestinal wall evoked particularly by antimicrobial activity in gut lumen, subsequently better absorption of nutrient could be attained. Similar trends were observed by several researchers who suggested in a series of reports similar antimicrobial mode of action for prebiotics (Shane, 2001 and Ferket, 2004), organic acids (Dibner, 2004), probiotics (Wenk, 2000 and Alçiçek et al., 2004) and their combinations (Bozkurt et al., 2009).

Mean relative weights of primary (bursa of Fabricius and thymus) and secondary (spleen) lymphoid organs are showed in Table (7). These lymphoid organs involved in the proliferation, differentiation and development of $\mathrm{T}$ or B lymphocytes. Their relative weights are easily measured and reflect the body's ability to afford lymphoid cells during an immune response (Heckert et al., 2002). Primary lymphoid organs are those organs whose function is to regulate the production and differentiation of lymphocytes and other leukocytes. While the secondary lymphoid organ functions are to trap antigens and serve as the site for interaction between foreign antigens and different types of leukocytes (Kuby, 1997). It is obvious that supplementation of different levels of oxygen activated Na CL (BioAktiv) improved the immune 
status as reflected by the relative weights of lymphoid organs. Thus, the relative weights of both primary lymphoid organs (bursa and thymus) were increased significantly in BioAktiv treated groups that recorded the highest relative values compared to the other treatments. Moreover, the lowest significant values were noticed for both the antibiotic group and the non supplemented in water drink one. Further, the remaining groups of BioAktiv ( $\mathrm{Na}$ CL0.5gm/1L) and the antibiotic one had intermediate values; like that they insignificantly differ from each other. Similar trend however insignificant were achieved for the secondary lymphoid organ (spleen). The current results may put forward trend toward improving immune response with supplemental BioAktiv. In this connection, Katanbaf et al. (1989) stated that the increase in the percentage lymphoid organs weight is considered as an indication of the immunological advances.

Table (7): Relative lymphoid organs weight of broilers fed on either antibiotic or different levels of oxygen activated $\mathrm{Na} \mathrm{CL}$ (BioAktiv).

\begin{tabular}{llllcc}
\hline Variable & \multicolumn{5}{c}{ Treatment } \\
\cline { 2 - 5 } & Control & Na CL0.5gm/1L & Na CL1gm/1L & Antibiotic \\
\hline Bursa & $0.136^{\mathrm{c}} \pm 0.003$ & $0.146^{\mathrm{b}} \pm 0.004$ & $0.154^{\mathrm{a}} \pm 0.002$ & $0.134^{\mathrm{c}} \pm 0.005$ & 0.0003 \\
Thymus & $0.224^{\mathrm{c}} \pm 0.005$ & $0.246^{\mathrm{b}} \pm 0.003$ & $0.257^{\mathrm{a}} \pm 0.002$ & $0.219^{\mathrm{c}} \pm 0.004$ & 0.0004 \\
Spleen & $0.103 \pm 0.009$ & $0.115 \pm 0.007$ & $0.118 \pm 0.006$ & $0.105 \pm 0.008$ & 0.17 \\
\hline
\end{tabular}

$\overline{\mathrm{a}, \mathrm{b} c \mathrm{c}}$ Means within the same row with different letters are significantly differ.

Beneficial effects of BioAktiv on immune system response may be cause to an indirect effect via changing the microbial population of the gastrointestinal tract (GIT) lumen. BioAktiv that is an oxygenized salt makes the gastrointestinal tract environment to be aerated consequently, kill off harmful organisms and at the same time increase the gastrointestinal tract concentration of oxygen. Oxygen could selectively kill the harmful anaerobic infectious bacteria. Unlike antibiotics, oxygen does not harm the beneficial bacteria that are essential to good health. Oxygen is a powerful detoxifier, so when the endogenous content of oxygen declines, toxins build up which can devastate the immunological and physiological functions. Moreover, immunity stimulation may also be cause to increase of serum globulin levels as obtained in the current results (Table 5).

On the other hand, the attained reduction in the lymphoid organ relative weights with supplemental antibiotic may be relation to the effect of antibiotic supplementation in reducing the population of grampositive bacteria, antibiotic growth promoters, give a slight advantage to gram negative bacteria to which groups E. coli, Salmonella and Campylobacter are belonging. In this respect, Yakheshi et al. (2011) found that antibiotics supplementation restrain gram positive bacteria that encourage the immune system response. They also added that antibody titration estimated against sheep red blood cells (SRBC's) was diminished by antibiotic supplementation.

\section{CONCLUSION}

It could be concluded from the current findings that, BioAktiv may consider a safe antibiotic alternative feed additive, having affirmative effect on gastrointestinal tract (GIT) health, performance and the physiological homeostasis of broiler chicks. Moreover, there was no need for increasing the water BioAktiv level beyond $\mathrm{Na}$ CL1gm/1L. However, the results require further clarifications and researches, particularly with the emphasis on immune responses and the GIT microbial population.

\section{ACKNOWLEDGEMENT}

The authors are grateful to Mr. Nizar Boussedra; BioAktiv Evolution, for providing BioAktiv supplement used in this study. www.bioaktivgmbh.de. 


\section{REFERENCES}

Abdel-Fattah, S. A., M.H. El-Sanhoury, N.M. El-Mednay and F. Abdel-Azeem (2008). Thyroid activity, some blood constituents, organs morphology and performance of broiler chicks fed supplemental organic acids. Inter. J. Poult. Sci.,7: 215-222.

Alçiçek, A., M. Bozkurt and M. Çabuk (2004). The effects of a mixture of herbal essential oil, an organic acid or a probiotic on broiler performance. S. Afr. J. Anim. Sci., 34: 217-222.

Amwele, H.R. (2004). The effect of ozone on the production of broiler. Master Technologiae in Agriculture, Port Elizabeth Technikon, University of Nelson Mandela Metropolitan.

Anjum, M.S and A.S. Chaudhry (2010). Using enzymes and organic acids in broiler diets. J. Poult. Sci., 47: $97-$ 105.

AOAC (2005). Association of Official Analytical Chemists. Official methods of analysis $18^{\text {th }}$ Ed. Washington D.C., USA.

Arun, K.P., V.R. Savaram, V.L.N.R. Mantena and R.S. Sita (2006). Dietary supplementation of Lactobacillus Sporogenes on performance and serum biochemico-lipid profile of broiler chicken. J. Poult. Sci., 43: 235-240.

Aureli, R., M. Umar Faruk and P.Guggenbuhl (2012). Effect of a formulation of Benzoic acid and Essential Oil compounds on growth performance, apparent ileal protein digestibility and intestinal morphology of broiler chickens. $3^{\text {rd }}$ Mediterranean Poultry Summit and $6^{\text {th }}$ Inter. Poult. Conf., 26 - 29 March 2012, Alex., Egypt.

BioAktiv. (1999). Das Pulver mit der großen Wirkung Informationsschrift BioAktiv GmbH.

Bonneau, M. and B. Laarveld. (1999). Biotechnology in animal nutrition, physiology and health. Livestock Prod. Sci., 59: 223-241.

Borsenberger, E. (2008). Use of BioActiv powder (Calcium Carbonaat Holland Green) in broiler feeding. Experimental report available on line at Website www.hollandgreen.com.

Bozkurt, M., K. Küçükyılmaz, A.U. Çatlı and M. Çınar (2009). The effect of single or combined dietary supplementation of prebiotics, organic acid and probiotics on performance and slaughter characteristics of broilers. South Afr. J. Anim. Sci., 2009, 39: 197-205.

De Rodas, B.Z., S. E. Gilliand and C.V. Maxwell (1996). Hypocholesterolemic action of lactobacillus acidophilus AT CC 43121 and calcium in swine with hypercholesterolemia induced by diet. J. Dairy. Sci.; 79: 2121-2128.

DEL-Agriculture (2000). Poultry ozone water sanitation systems. San Luis Obispo,CAS93401. www.delozone.com.

Denbow, D. M. (2000). Gastrointestinal anatomy and physiology. Chapter, 12 appeared in Sturkie's Avian Physiology, Fifth Edition.

Dibner, J. ( 2004). Organic acids: Can they replace antibiotic growth promoters? Feed Int. 25: 14-16.

Dibner, J.J and P. Buttin (2002). Use of organic acids as a model to study the impact of gut microflora on nutrition and metabolism. J. App. Poult. Res., 11: 453-463.

Duncan, D.B. (1955). Multiple range and multiple "F" test. Biometrics, 11: 1-42.

Ferket, P.R. (2004). Alternatives to antibiotics in poultry production: Responses, practical experience and recommendations. Nutritional biotechnology in the feed and food industries. In: Proc. Alltech's $20^{\text {th }}$ Annual Symp. Eds. Lyons, T.P. \& Jacques, K.A., Nottingham University Press. pp. 57-67.

Gaughan, J. (2001): The Effect of BioActiv On the Health and Growth Performance of Pigs University of Queensland Gatton / Queensland School of Animal Studies.

Gaughan, J.; S. Holt; I. Williams and A. King (2007). The Effect of BioActiv on the health and growth performance of pigs. An experimental report issued by the Australian pig institute, available on line at www.hollandgreen.com.

Goldstein, D.L. and E. Skadhauge (2000). Renal and extrarenal regulation of body fluid composition. In: Sturkie's avian physiology. Ch. 11. Ed Whittow GC. Academic Press, San Diego. 


\section{El-Sanhoury}

Griminger, P. (1986). Lipid Metabolism in "Avian Physiology" Edited by P.D Sturkie. $4^{\text {th }}$ Ed. Springer-Verlag, Inc., New Work, NY.USA.

Guzel-Seydim, Z. B., Jr. P. I. Bever and A. K. Greene (2004). Efficacy of ozone to reduce bacterial populations in the presence of food components. Turkey, USA: Elsevier Ltd. p. $475-479$.

Heckert, R. A., I. Estevez, E. Russek-Cohen, and R. Pettit-Riley (2002). Effects of density and perch availability on the immune status of broilers. Poult. Sci., 81:451-457.

Huyghebaert G., R. Ducatelle and F. V. Immerseel (2010). An update on alternatives to antimicrobial growth promoters for broilers. The Vet. J., 10 :1016-

Katanbaf, M.N., E.A. Dunnington and P.B. Siegel (1989). Restricted feeding in early and late-feathering chickens. Growth and physiological responses. Poult. Sci., 68: 344-351.

Kuby, J. (1997). Immunology. W. H. Freeman and Co., New York, NY, PP.40-70, 99-225.

Malik, C.P. and Singh, B. (1980). Plant enzymology and histoenzymolog. Kalyani publishers, New Delhi Ludhiana, Chapter 6,166.

Muhammaed, S. and A. S. Chaudhry (2010). Using enzymes and organic acids in broiler diets. The J. Poult. Sci., 47:97-105.

National Research Council (1994). Nutrient Requirements of Poultry 9th rev .ed. 1994 National Academy Press Washington, DC .

Osman, A.M. (1982). Amylase in chicken intestine and pancreas. Comp. Biochem. Physiol., 73B, 571.

Phillip, I., M. Casewl; T. Cox, B.De.Groot; C.Friis; R.Jones, C. Nightingale, R. Preston and J. Wadell (2004). Does the use of antibiotic in food animals pose a risk to human health? A critical review of published data. J. Antimicrobial chemotherapy, 53: 28-52.

Samik, K.P., H. Gobinda, K.M. Manas and S. Gautam (2007). Effect of organic acid salt on the performance and gut health of broiler chicken. J. Poult. Sci., 44: 389-395.

SAS., 2004. SAS procedure Guide, Version 6.12 th. SAS Institute, Cary, NC.,

Shane, M.S. (2001). Mannan oligosaccharides in poultry nutrition: mechanism and benefits. In: Proc. Alltech's $17^{\text {th }}$ Annual Symp., Science \& Technology in the Feed Industry. Eds Lyons, T.P. \& Jacques, K.A., Nottingham University Press. pp. 65-77.

Theruvathu, J. A., Flyunt, R., Aravindakumar, C.T. and Von Sonntag (2001). Rate constants of ozone reactions with DNA, its constituents and related compounds. German. J. Chem. Society. Perkin Trans. p. 269 - 274.

Wenk, C. (2000). Recent advances in animal feed additives such as metabolic modifiers, antimicrobial agents, probiotics, enzymes and highly available minerals. Review. Asian-Aust. J. Anim. Sci. 13: 86-95.

Wentworth and Ringer., (1986). Lipid Metabolism in "Avian Physiology" Edited by P.D Sturkie. $4^{\text {th }}$ Ed. SpringerVerlag, Inc., New Work, NY.USA.

Yakhkeshi, S; S. Rahimi and K.N. Gharib (2011). The effect of comparison of herbal extract, antibiotic, probiotic and organic acid on serum lipoids, immune response, GIT microbial population, intestinal morphology and performance of broilers. J. Med. Plant, 10; 80-95.

Yesilbag, D. and I. Colpan (2006). Effects of organic acid supplemented diets on growth performance, egg production and quality and on serum parameters in laying hens. Revue Med. Vet., 157: 280-284. 
تأثير استخدام كلوريد الصوديوم المنشط بالأكسجين كبديل للمضادات الحيوية علي الأداء الإنتاجي والنشاط

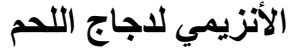

\author{
مر اد حامد شاكر السنهوري \\ قسم انتاج الدواجن - كلية الزراعة - جامعة عين شمس المس
}

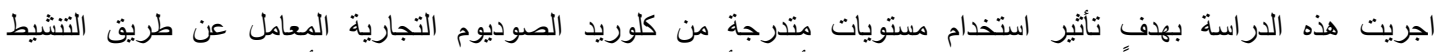

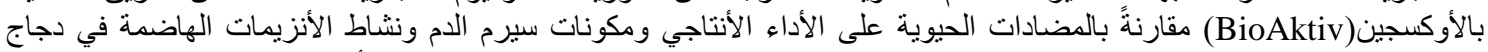

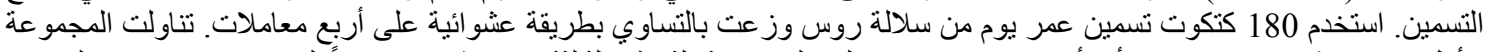

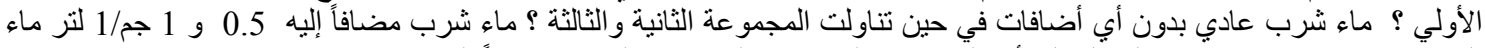

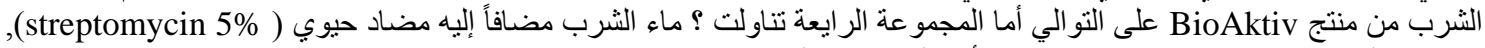
استمرت المعاملات حتى عمر 35 يوم. وكانت أهم النتائج كما يلي:-

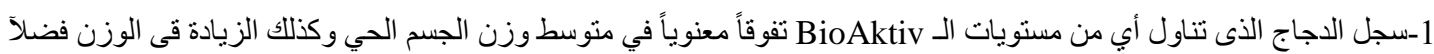

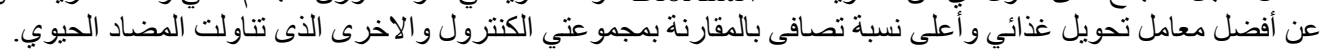

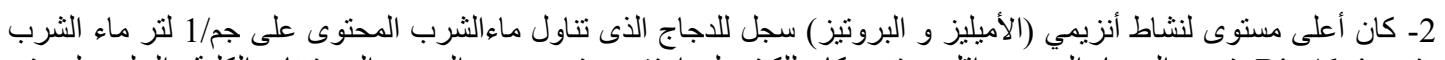

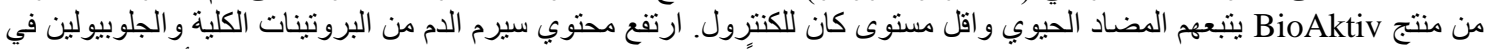

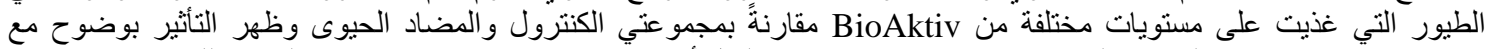

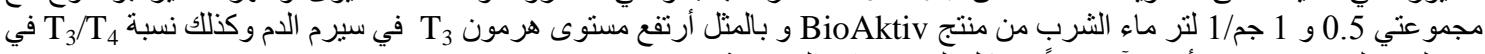

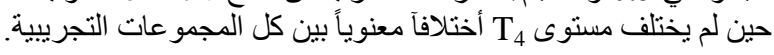

3-اضافة الـ BioAktiv في ماء الثرب المقدم لكتاكيت اللحم كان له تأثير معنوى على إنخفاض مستوى الليبيدات و الكولسترول في

الدم بينما لم تتأثز وظائف الكبد و الكليتين.

نستخلص من هذه الدراسة أن BioAktiv يعتبر بديلاً أمناً للمضادات الحيوية لما له من تأثير جيد على القناه الهضمية وأداء

النمو و الصفات الفسيولوجية في دجاج التسمين. 